\title{
Ketepatan Pilihan Kata dalam Campur Kode pada Anak Usia Dini Hasil Perkawinan Endogami dalam Berkomunikasi dengan Anggota Keluarga dan Teman Sejawat
}

\author{
${ }^{1}$ Erni Subriani ${ }^{2}$ Arifuddin ${ }^{3}$ Lalu Muhaimi \\ ${ }^{123}$ Universitas Mataram \\ ernisubriani@gmail.com
}

\begin{abstract}
Abstrak: Penelitian ini bertujuan untuk mengetahui ketepatan pemilihan kata dalam campur kode anak usia dini hasil perkawinan endogami saat berkomunikasi dengan anggota keluarga dan teman sejawat. Jenis penelitian ini merupakan penelitian deskriptif dengan menggunakan pendekatan kualitatif. Adapun subjek penelitian terdiri dari tiga orang anak yaitu NQD, AHA, dan QIM dengan rentang usia empat sampai lima tahun. Metode pengumpulan data yang digunakan dalam penelitian ini yaitu metode observasi, wawancara, metode simak dengan teknik rekam dan catat. Analisis data dilakukan dengan tahapan transkripsi, identifikasi, klasifikasi, analisis dan verivikasi. Berdasarkan hasil analisis data diperoleh hasil bahwa anak usia 4-5 tahun sudah mampu menggunakan pilihan kata dalam campur kode dengan tepat sesuai dengan arti dan maksud tuturannya.
\end{abstract}

Kata Kunci: Ketepatan, Campur Kode, komunikasi

\section{PENDAHULUAN}

Bahasa merupakan suatu anugerah yang diberikan Tuhan Yang Maha Esa kepada manusia. Manusia sebagai makhluk sosial yang memiliki akal dan pikiran tentunya tidak dapat terlepas dari apa yang disebut dengan bahasa. Bahasa sejatinya suatu hal yang kita pahami sebagai alat untuk berkomunikasi, namun satu hal yang perlu disadari bahwa setiap anak yang terlahir ke dunia tidak begitu saja dapat langsung berbicara dan menggunakan bahasa dalam berkomunikasi. Seiring waktu, anak mulai dapat mengucapkan sesuatu dan mencoba berkomunikasi dengan orang tua lewat bahasa.

Setiap anak memiliki kemampuan yang berbeda-beda dalam berkomunikasi. Anak yang sebelumnya belum bisa berbicara lamakelamaan akan lancar berbicara setelah memeroleh bahasa ibunya atau yang dikenal dengan istilahbahasa pertama (B1). Pada dasarnya, bahasa ibu adalah bahasa yang pertama kali dikuasai oleh seorang anak sejak kecil yang menjadi dasar pemahamannya secara alamiah. Proses seorang anak menguasai bahasa ibu merupakan suatu hal yang bisa dikatakan menakjubkan. Sejak umur satu sampai dengan satu setengah tahun seorang anak mulai mengeluarkan bentuk-bentuk bahasa yang telah dapat diidentifikasikan sebagai kata. Ujaran satu kata ini tumbuh menjadi ujaran dua kata dan akhirnya menjadi kalimat yang komplek menjelang umur empat atau lima tahun.

Setiap anak yang terlahir ke dunia akan tumbuh bersamaan dengan pertumbuhan bahasanya dan dengan kemampuan yang berbeda-beda. Perbedaan kemampuan berbicara atau memproduksi bahasa pada anak bisa disebabkan oleh berbagai faktor. Salah satu faktor yang memengaruhi kemampuan berbahasa pada anak khususnya anak usia dini ialah bahasa yang digunakan orang tuanya. Orang tua yang berlatar belakang perkawinan dengan berbeda etnis, suku, dan daerah atau yang dikenal dengan istilah perkawinan eksogami dan juga latar belakang perkawinan orang tua antar sesama etnis atau endogamI tentunya akan berpengaruh terhadap bahasa yang akan digunakan dalam keluarga tersebut. Dalam keadaan seperti ini, akan muncul variasi bahasa dalam satu keluarga yang akan memberikan dampak terhadap bahasa yang akan digunakan oleh keturunannya, yaitu bahasa si anak. 
Kebanyakan pernikahan campuran yang paling terlihat yaitu bahasa si ibu dengan bahasa si ayah berbeda, sehingga terjadilah dwibahasa dalam satu keluarga. Orangtua yang berada pada kondisi seperti ini akan merasa kebingungan dengan bahasa apa yang akan diajarkan kepada anak-anaknya. Pada keadaaan seperti itu, orangtua akan memutuskan untuk lebih mendahulukan menggunakan bahasa Indonesia sebagai bahasa pertama yang diajarkan kepada anak, meskipun dalam sesekali berkomunikasi menggunakan bahasa daerah dengan leksikon yang dimengerti oleh kedua belah pihak.

Anak yang terlahir dari hasil pernikahan campuran seperti ini cenderung akan menggunakan bahasa Indonesia sebagai bahasa pertamanya, namun tidak menutup kemungkinan si anak akan mengetahui dan bisa mengunakan bahasa daerah orangtuanya sebagai bahasa kedua (B2). Ketika usia si anak lebih dewasa, lebih lancar diajak berkomunikasi, orangtua cenderung mengajak anak untuk berbahasa daerah, tetapi si anak akan lebih mudah menjawab dengan bahasa Indonesia karena bahasa tersebut yang lebih dikuasai.

Kenyataan lainnya, perkawinan yang terjadi antara orang tua dengan latar belakang sesama etnis atau yang disebut endogami menggunakan bahasa daerah sebagai bahasa keseharian dalam berkomunikasi, namun hal yang terjadi justru saat berkomunikasi dengan si anak, bahasa Indonesialah yang seringkali diajarkan dan digunakan sebagai bahasa pertama. Anak yang terlahir dari perkawinan sesama etnis seperti ini menarik perhatian peneliti, sebab tidak jarang dalam penggunaan bahasanya si anak menggunakan bahasa Indonesia dalam berkomunikasi namun tanpa sadar si anak seringkali menyisipkan kosakata yang ternyata adalah bahasa daerah orangtuanya yang tanpa sadar terselip dalam kalimat-kalimat yang diujarkan tanpa si anak mengerti apakah lawan bicaranya memahami atau tidak arti dari kata yang diujarkannya tersebut.
Kasus pernikahan dengan latar belakang eksogami maupun endogami seperti ini sudah sering terjadi di berbagai daerah, contohnya pada kasus perempuan Lombok yang menikah dengan laki-laki Jawa setelah menikah tinggal di Lombok, perempuan Jawa menikah dengan laki-laki Lombok setelah menikah tinggal di Lombok dan beberapa contoh permikahan sesama etnis dan berbeda etnis lainnya.

Sesungguhnya setiap anak akan berkomunikasi dengan penggunaan serta penguasaan bahasa yang berbeda-beda. Perbedaan-perbedaan dalam produksi bahasa anak khususnya pada anak usia dini menjadi suatu hal yang unik dan menarik untuk dikaji lebih mendalam. Keunikan ini terlihat pada saat si anak menggunakan bahasa pertama dan atau bahasa keduanya secara bersamaan diluar kesadaran pada saat berkomunikasi dengan anggota keluarga dan teman sejawatnya. Fenomena semacam ini bisa saja menjadi suatu problema bagi lawan bicara si anak. Problema tersebut dilihat ketika si anak hendak menyampaikan maksud ujarannya atau saat berkomunikasi dengan orang lain, sebab seringkali campur kode yang dilakukan si anak saat berkomunikasi membuat lawan bicaranya menjadi kebingungan akan maksud yang disampaikan. Selain itu, penyisipan kosakata bahasa daerah atau bahasa ibu yang acapkali digunakan oleh si anak menjadi perhatian tersendiri peneliti apakah kosakata yang digunakan dalam campur kode tersebut tepat atau tidak penggunaannya dalam kalimat yang diujarkan .

Melihat bahwa terdapat beberapa penelitian terkait penggunaan bahasa anak dalam berkomunikasi, namun banyak yang masih sebatas hipotesis dan belum memberikan jawaban menyeluruh tentang apa yang hendak dikaji dalam penelitian ini, untuk itu akan disusun penelitian dengan judul "Ketepatan Pilihan Kata dalam Campur Kode pada Anak Usia Dini hasil Perkawinan Endogami dalam Berkomunikasi dengan Anggota Keluarga dan Teman Sejawat”. 


\section{Rumusan Masalah}

Dalam upaya menemukan solusi terhadap masalah di atas, penelitian ini mengajukan rumusan masalah sebagai yaitu:

1. Bagaimana ketepatan pilihan kata dalam campur kode pada anak usia dini hasil perkawinan endogami dalam berkomunikasi dengan anggota keluarga dan teman sejawat?

\section{Tujuan Penelitain}

Adapun tujuan yang hendak dipecahkan dalam penelitian ini adalah sebagai berikut untuk mengidentifikasi, menganalisis dan mendeskripsikan ketepatan pilihan kata dalam campur kode anak usia dini hasil perkawinan endogami dalam berkomunikasi dengan anggota keluarga dan teman sejawat.

\section{Manfaat Penelitian}

Adapun manfaat yang didapat dari

penelitian ini adalah sebgai berikut:

1. Secara teoritis, penelitian ini diharapkan dapat memberikan kontribusi untuk mengembangkan ilmu pegetahuan serta memperoleh deskripsi yang sahih dan objektif berdasarkan data sebenarnya yang diperoleh langsung khususnya pada ranah produksi ujaran penggunaan bahasa pada anak usia dini dari hasil pernikahan endogami. Selain itu, penelitian ini diharapkan dapat bermanfaat sebagai pengembangan teori bahasa, dan sosiolinguistik khususnya.

2. Secara praktis, penelitian ini diharapkan dapat memberikan kontribusi dan pemahaman bagi para pembaca dan juga mahasiswa tentang pengajaran bahasa Indonesia yang kemungkinan bisa menjadi bahasa pertama dan bahasa kedua. Selain itu, penelitian ini diharapkan dapat menjadi bahan masukan serta memperkaya khazanah pengetahuan tentang perkembangan bahasa anak khususnya di PAUD terkait penggunaan bahasa Indonesia.

\section{LANDASAN TEORI}

\section{A. Bahasa Pertama dan Bahasa Kedua}

Bahasa ibu atau yang dikenal dengan istilah bahasa pertama (B1) ialah bahasa yang dikuasai manusia sejak lahir melalui interaksi dengan sesama anggota masyarakat bahasanya, seperti keluarga dan masyarakat lingkungannya dan digunakan sebagai bahasa dalam berkomunikasi sehari-hari.Setiap anak yang terlahir normal akan belajar bahasa ibu dalam tahun-tahun pertamanya dan proses itu terjadi hingga kira-kira berumur lima tahun (Sulihami, 2014). Sejalan dengan itu, Chaer dan Agustina( 2004:81) mengungkapkan bahwa bahasa ibu lazim juga disebut bahasa pertama karena bahasa itulah yang pertama-tama dipelajarinya. Sependapat dengan hal itu, Solehan, dkk (2011:25) juga mengatakan bahwa bahasa pertama adalah bahasa yang pertama kali diperoleh dan dikuasai oleh seorang anak.

Pembahasan mengenai bahasa pertama tentu saja tidak bisa terlepas dari kata atau istilah "pemerolehan". Sejalan dengan itu Chaer (2002:167) mengungkapkan bahwa terdapat dua proses yang terjadi ketika seorang anak sedang memperoleh bahasa ibu atau bahasa pertamanya (B1), yaitu proses kompetensi dan proses performansi. Kempotensi adalah proses penguasaan tata bahasa yang berlangsung secara tidak disadari, sedangkan performansi ialah kemampuan memahami dan kemampuan melahirkan atau menerbitkan kalimat-kalimat baru yang dalam linguistik transformasi generatif disebut juga perlakuan atau pelaksanaan bahasa.

Telah diungkapkan di atas bahwa acuan dalam penelitian ini adalah penggunaan bahasa pada anak usia dini, sedangkan teori yang dapat digunakan sebagai tonggak dasar pada pembahasan selanjutnya terkait pemerolehan bahasa ibu atau bahasa pertama (B1) yakni teori stimulus-respon yang dikemukakan oleh kaum behaviorisme (Skinner,1957) yang mengatakan bahwa bahasa adalah hasil perilaku stimulusrespon. Maka apabila seorang anak ingin memperbanyak penggunaan ujaran maka ia harus memperbanyak penerimaan stimulus. Oleh karena itu, peranan lingkungan sebagai sumber datangnya stimulus menjadi dominan dan sangat penting di dalam membantu proses pembelajaran bahasa. Selain itu, kaum behaviorisme juga berpendapat bahwa proses 
perolehan bahasa adalah proses pembiasaan. Itulah sebabnya, semakin sering seorang pembelajar terbiasa merespon stimulus yang datang padanya, semakin memperbesar kemungkinan aktivitas perolehan bahasanya (Hamid, 1987:14-15).

Selanjutnya bahasa kedua anak, seperti halnya bahasa pertama, tidak terlepas dari kata "pemerolehan" dan juga "pembelajaran". Mengacu pada pemerolehan bahasa kedua (B2), banyak pakar yang menyebutnya dengan istilah pembelajaran bahasa (language learning). Digunakannya istilah pembelajaran bahasa karena diyakini bahwa bahasa kedua dapat dikuasai hanya dengan proses belajar, dengan cara sengaja dan sadar, namun bagi sebagian orang yang menyebut pembelajaran bahasa kedua dengan sebutan pemerolehan bahasa kedua beranggapan bahwa bahasa kedua (B2) juga merupakan sesuatu yang dapat diperoleh baik secara formal dalam pendidikan formal, maupun informal dalam lingkungan kehidupan.

Teori kontranstif menyatakan bahwa keberhasilan belajar bahasa kedua banyak ditentukan oleh keadaan linguistik bahasa yang telah dikuasai oleh pembelajar sebelumnya (Klein, 1986:5).Artinya berbahasa kedua adalah proses transfer. Maka, struktur bahasa yang sudah dikuasai banyak mempunyai kesamaan dengan bahasa yang dipelajari, akan terjadilah semacam permudahan dalam proses transfernya. Sebaliknya, jika struktur keduanya memiliki perbedaan, maka akan terjadilah kesulitan bagi pembelajar untuk menguasi bahasa keduanya itu.

Untuk mengukur kemampuan bahasa pada anak usia dini bisa dilakukan dengan beberapa tes. Salah satu alat ukur tersebut adalah riset kemajuan anak selama yang normal dengan tujuan eksplorasi terhadap efek dari berbagai faktor lingkungan. Misalnya kedwibahasaan, sangat terpengaruh oleh jumlah waktu yang digunakan anak untuk menonton televisi, kedudukan anak dalam keluarga, urutan kelahiran dan terhadap perkembangan bahasanya (Dale dalam Mar'at, 2005:76).

\section{B. Kedwibahasaan}

Berdasarkan

KBBI

(2007),

kedwibahasaan dapat didefinisikan sebagai suatu perihal mengenai pemakaian atau penguasaan dua bahasa (seperti penggunaan bahasa daerah di samping bahasa nasional) atau dikenal dengan istilah bilingualisme.

Terdapat berbagai jenis kedwibahasaan menurut Kamaruddin (dalam Santosa: 2005). Jenis kedwibahasaan yang dimaksud diantaranya kedwibahasaan apabila ditinjau dari ketersebarannya, kedwibahasaan itu dibagi menjadi kedwibahasaan perorangan (individual bilingualism) yang mengacu kepada kemampuan individu dalam menggunakan dua bahasa dan kedwibahasaan masyarakat (societal bilingualism), yaitu kemampuan sekumpulan individu dalam suatu kelompok masyarakat dalam menggunakan dua bahasa dalam melakukan komunikasinya. Chaer dan Agustina (2010: 84) juga mengatakan bahwa kedwibahasaan atau bilingualisme merupakan penggunaan dua bahasa atau dua kode bahasa. Kedwibahasaan adalah kebiasaan menggunakan dua bahasa atau lebih secara bergantian.

Dilihat dari tingkat kedwibahasaannya, terdapat jenis kedwibahasaan tingkat minimal dan maksimal. Pada kedwibahasaan tingkat minimal menganggap individu sudah dinyatakan sebagai individu yang dwibahasawan apabila individu itu mampu untuk melahirkan tuturan yang berarti dalam bahasa lain. Selanjutnya, kedwibahasaan maksimal menganggap bahwa individu adalah dwibahasawan apabila individu itu mampu untuk melahirkan tuturan dalam dua bahasa secara memuaskan.

Individu dapat menjadi dwibahasawan karena disebabkan oleh beberapa faktor. Adapun faktor-faktor yang dimaksud seperti faktor perpindahan penduduk, perkawinan campur, guyup tutur yang heterogen, urbanisasi penduduk, dan pendidikan. Adanya faktorfaktor tersebut dapat mempengaruhi terjadinya suatu proses kedwibahasaan, baik pada anak- 
anak maupun pada orang dewasa (Grosjean dalam Nugroho, 2011:31).

Berdasarkan paparan di atas peneliti dapat menggaris bawahi bahwa kedwibahasaan itu pada dasarnya merupakan kemampuan yang dimiliki seseorang, baik individu ataupun masyarakat, yang menguasai dua bahasa dan mampu untuk menggunakan kedua bahasanya tersebut dalam melakukan komunikasi seharihari secara bergantian dengan baik. Sedangkan seseorang yang terlibat dalam kegiatan atau praktik menggunakan dua bahasa secara bergantian itulah yang disebut dengan bilingualnya atau yang kita kenal dengan istilah dwibahasawan.

\section{Campur Kode}

Dalam dunia kedwibahasaan seorang individu ataupun kedwibahasaan pada anak usia dini hasil perkawinan endogami, pastilah dijumpai beberapa pengertian tentang fenomena bahasa pada masyarakat yang multilingual. Beberapa pengertian yang dimaksud setidaknya mengenai pertukaran bahasa atau alih kode dan percampuran bahasa atau campur kode. Dalam hal ini yang perlu digaris bawahi adalah percampuran bahasa atau campur kode.

Peristiwa campur kode terjadi apabila seorang penutur bahasa, misalnya bahasa Indonesia memasukkan unsur-unsur bahasa daerah ataupun bahkan memasukkan unsurunsur bahasa asing ke dalam pembicaraan bahasa Indonesianya tersebut. Dengan kata lain, seseorang yang berbicara dengan kode utama bahasa Indonesia yang mempunyai fungsi keotonomiannya, sedangkan kode bahasa daerah atau bahasa asing yang terlibat dalam kode utama tersebut merupakan serpihanserpihan saja tanpa fungsi atau keotonomian sebagai sebuah kode (Aslinda dan Syafyahya dalam Nugroho, 2011:49). Secara sederhana, campur kode diartikan sebagai suatu gejala pencampuran pemakaian bahasa karena berubahnya situasi tutur.

Dalam KBBI (2007), campur kode adalah penggunaan satuan bahasa dari satu bahasa ke bahasa yang lain untuk memperluas gaya bahasa ataupun ragam bahasa, pemakaian kata, klausa, idiom, sapaan, dan lain sebagainya. Terdapat tiga jenis campur kode yang dikemukakan oleh Jendra (dalam Nugroho, 2011:53). Ketiga jenis campur kode menurutnya tersebut antara lain adalah sebagai berikut:

\section{a. Inner Code Mixing}

Campur kode yang dimaksud adalah campur kode yang menggunakan elemenelemen dari bahasa asli atau bahasa asal dalam peristiwa campur kodenya yang masih terdapat hubungan dengan bahasa yang dicampur. Misalnya, beberapa elemen yang masih berhubungan di dalam campur kode bahasa Indonesia, seperti bahasa Jawa, bahasa Sunda, bahasa Bali, Sumbawa, dan lain sebagainya.

b. Outer Code Mixing

Jenis campur kode yang dimaksud merupakan campur kode yang menggunakan elemen-elemen dari bahasa asing dalam peristiwa campur kodenya,misalnya seorang penutur berbahasa Indonesia yang dalam komunikasinya menyisipkan elemen dari bahasa Prancis, bahasa Inggris, bahasa Belanda, dan lain sebagainya. Maka, penutur tersebut telah melakukan outer code mixing.

c. Hybrid Code Mixing

Jenis campur kode yang dimaksud dapat menerima elemen apapun dalam peristiwa campur kodenya, baik elemen bahasa asal ataupun elemen bahasa asing dalam kalimat atau klausanya. Dalam sebuah kalimat, pastilah terdapat unsurunsur (konstituen) pembentuk kalimat tersebut. Unsur-unsur pembentuk kalimat yang dimaksud dapat berupa kata, frasa, ataupun klausa.Setiap unsur tersebut dapat dibeda-bedakan berdasarkan kategori, fungsi, ataupun perannya dalam kalimat tersebut.

Beberapa jenis kategori yang dapat menjadi unsur dalam sebuah kalimat adalah nomina (kata benda), pronomina (kata ganti), verba (kata kerja), adjektiva (kata sifat), 
numeralia (kata bilangan), adverbia (kata keterangan), dan kata tugas seperti preposisi (kata depan), konjugasi (kata penghubung), dan partikel (Arifin dan Junaiyah dalam Nugroho, 2011:54).

Terjadinya campur kode yang secara tidak sadar dilakukan oleh anak usia dini dalam berkomunikasi disebabkan oleh tidak adanya padanan kata dalam bahasa yang digunakan untuk menyatakan maksud, atau bisa juga terjadi dikarenakan pilihan kata yang digunakan tersebut lebih sering digunakan sehingga kosakata yang diingatlah yang acapkali dipilih oleh si anak untuk menyatakan suatu maksud. Sesuai dengan pemahaman peneliti pada paparan di atas, keterkaitan campur kode dengan penelitian ini mencakup ketepatan pilihan kata dalam campur kode yang digunakan oleh anak usia dini hasil perkawinan endogami dalam berkomunikasi dengan anggota keluarga dan teman sejawat.

\section{E. Sosiolinguistik}

Sosiolinguistik merupakan salah satu cabang ilmu bahasa yang mempelajari atau membahas aspek-aspek kemasyarakatan bahasa, khususnya perbedaan-perbedaan atau variasi yang terdapat dalam bahasa yang berkaitan dengan faktor-faktor kemasyarakatan.

Ditinjau dari nama sosiolinguistik tentu menyangkut sosiologi dan linguistik, karena itu sosiolinguistik mempunyai kaitan erat dengan kedua kajian tersebut. Sosio adalah masyarakat dan linguistik adalah kajian bahasa. Jadi, sosiolonguistik adalah kajian tentang bahasa yang dikaitkan dengan kondisi kemasyarakatan (Sumarsono, 2014: 1).

Menurut Soeparno (2002: 25), sosiolinguistik adalah subdisiplin linguistic yang mempelajari bahasa dalam kaitannya dengan faktor-faktor kemasyarakatan atau faktor sosial. Masalah utama yang dibahas atau dikaji dalam sosiolinguistik antaralain, mengkaji bahasa dalam konteks sosial dan kebudayaan, menghubungkan factor-faktor kebahasaan, ciri-ciri bahasa, ragam bahasa, situasi, faktor-faktor sosial danbudaya, serta mengkaji fungsi-fungsi sosial dan penggunaan bahasa dalam masyarakat. Jadi, dapat disimpulkan bahwa sosiolinguistik adalah cabang linguistik yang mempelajari hubungan antara perilaku sosial dan perilaku bahasa.

\section{F. Fungsi Bahasa}

Bahasa didalam struktur budaya memiliki kedudukan, fungsi serta peran ganda ialah sebagai akar serta produk budaya yang sekaligus berfungsi sebagai sarana berfikir dan sarana pendukung pertumbuhan serta perkembangan ilmu pengetahuan dan teknologi (Sunaryo, 2000:6). Secara sederhana, fungsi bahasa seperti yang peneliti pahami ialah suatu alat yang digunakan sebagai sarana berkomunikasi dengan orang lain atau lawan bicara baik bahasa lisan maupun maupun bahasa tulis. Fungsi seperti ini sering disebut sebagai fungsi pragmatis.

Searle (dalam Leech, 1993:164) menggolongkan lima macam bentuk tuturan yang menunjukkan fungsi pragmatis sebagai fungsi komunikatif dalam tindak tutur sebagai berikut.

1) Fungsi Asertif

Tindak tutur asertif mempunyai fungsi memberitahu orang-oang (penutur) mengenai sesuatu. Fungsi asertif ini terkait pada kebenaran proposisi yang diungkapkan misalnya: menyatakan, mengusulkan, membual, mengemukakan pendapat, melaporkan, menunjukkan, menyebutkan, memberitahukan, mempertahankan, membanggakan dan menyombongkan. Dilihat dari segi sopan santun, ilokusi ini cenderung netral, yakni termasuk kategori kerjasama (kolaboratif).

\section{Contoh: Saya lahir di Mataram.}

2) Fungsi Direktif

Tindak tutur yang berfungsi untuk membuat penutur akan melakukan sesuatu atau menimbulkan efek berupa tindakan yang dilakukan oleh penutur disebut sebagai fungsi direktif. Fungsi ilokusi ini misalnya: memesan, memerintah, memohon, memberi nasehat, menyuruh, menantang, 
Jurnal Ilmu Sosial dan Pendidikan

http://ejournal.mandalanursa.org/index.php/JISIP/index

Terakreditasi Peringkat 5 (No. SK: 85/M/KPT/2020)

menyarankan, menganjurkan, memastikan, mengajak, mengijinkan, menawar, melarang, mendesak, memperingatkan, dan menuntut

Contoh: Tolong bukakan pintu itu!

3) Fungsi Komisif

Fungsi komisif yaitu tindak tutur yang menyatakan bahwa penutur akan melakukan sesuatu. Ilokusi ini terkait pada suatu tindakan di masa depan atau yang akan datang. Tindak ilokusi ini misalnya: menjanjikan, bersumpah, menawarkan, memanjatkan doa, menolak, dan mengancam.

Contoh: Iya janji, nanti habis mandi baru saya makan.

4) Fungsi Ekspresif

Tindak tutur ini berfungsi untuk mengekspresikan perasaan dan sikap penutur terhadap keadaan yang tersirat dalam ilokusi misalnya: mengucapkan terima kasih, mengucapkan selamat, memberi maaf, mengecam, memuji, mengucapkan belasungkawa, mengkritik, mengeluh, menyalahkan, menyesal dan sebagainya. Tindak tutur ilokusi ini cenderung menyenangkan, karena itu secara intrinsik ilokusi ini sopan, kecuali ilokusi-ilokusi ekspresif mengecam, menyesal dan menyalahkan.

Contoh: Terimakasih ya, saya suka kadonya.

5) Fungsi Deklaratif

Hasil ilokusi ini mengakibatkan adanya kesesuaian antara proposisi dengan realitas, misalnya: mengundurkan diri, memecat, memberi nama, menjatuhkan hukuman, atau kalimat yang tidak memerlukan jawaban dari lawan bicara. Tindakan-tindakan ini merupakan kategori tindak tutur yang sangat khusus.

Contoh: Saya tadi sudah mandi sama ibu.

Dalam arti yang paling sederhana "fungsi" dapat dipandang sebagai padanan kata "penggunaan". Dengan demikian, bila berbicara tentang fungsi bahasa dapat diartikan sebagai cara orang menggunakan bahasa mereka atau bahasa-bahasa mereka bila mereka berbahasa lebih dari satu bahasa Halliday (dalam Chaer, 2004: 20). Fungsi bahasa akan terlihat apabila orang menggunakan bahasa lebih dari satu bahasa seperti halnya pemakaian bahasa kedua yang digunakan oleh anak usia dini saat berkomunikasi.

Fungsi bahasa yang digunakan anak dalam pembicaraan dengan anggota keluarga dan teman sejawatnya didasarkan pada tujuan berkomunikasi. Anak berbicara menggunakan bahasa pertama dan bahasa keduanya menurut fungsi yang dikehendakinya bisa terjadi sesuai dengan konteks dan situasi komunikasi.

\section{PEMBAHASAN}

1. Ketepatan Pilihan Kata dalam Campur Kode pada Anak Usia Dini

\begin{tabular}{|c|c|c|}
\hline No & Ujaran Anak & $\begin{array}{l}\text { Nama } \\
\text { Anak }\end{array}$ \\
\hline $\begin{array}{l}3 \\
4 \\
5\end{array}$ & $\begin{array}{l}\text { Yang hitam itu merang } \\
\text { Ndak mau saya makan itu } \\
\text { padang! } \\
\text { Saya lagi potong empaq } \\
\text { Jangan tijak Alin! } \\
\text { Nanti tumpak buek }\end{array}$ & NQD \\
\hline $\begin{array}{l}6 \\
7 \\
8 \\
9 \\
10\end{array}$ & $\begin{array}{l}\text { Bembek tu, ada tai bembek } \\
\text { Ndak sugul apinya } \\
\text { Ndek gemes! } \\
\text { Siapa mau taek ini ? } \\
\text { Hujan beleq siapa mau mandiq } \\
\text { ujan? }\end{array}$ & AHA \\
\hline $\begin{array}{l}11 \\
12 \\
13 \\
14\end{array}$ & $\begin{array}{l}\text { Waa, kenapa sepuluh adenan? } \\
\text { Kita tunggu dia sampai jira } \\
\text { besikir dunu } \\
\text { Wa jina penokna, op sudah } \\
\text { Oo kakak itu hp kakak di anok } \\
\text { meja } \\
\text { Satu sama dua na, teres tiga na }\end{array}$ & QIM \\
\hline
\end{tabular}

Berdasarkan data ujaran anak usia 4-5 tahun tersebut, menunjukkan bahwa ketiga subjek penelitian acapkali melakukan campur kode dengan menyisipkan penggunaan kosakata bahasa daerah atau bahasa ibu pada saat 
berkomunikasi dengan anggota keluarga dan teman sejawat. Penyisipan kosakata bahasa daerah yang dilakukan si anak pada saat berkomunikasi terjadi di luar kesadaran dan pemahaman anak tentunya. Dalam situasi ini, anak melakukan campur kode dengan maksud ingin mengemukakan sesuatu kepada orang lain yaitu lawan bicaranya, atau karena ingin memberikan reaksi terhadap sesuatu yang didengarnya dengan menggunakan bahasa yang dipahami dan biasa di dengar di lingkungan tempat tinggalnya.

a. Ketepatan Pilihan Kata dalam Campur Kode NQD

Data pertama sesuai dengan paparan tabel di atas NQD mengatakan yang hitam itu merang. Pada tuturan tersebut terjadi campur kode dengan adanya penyisipan leksikon merang dalam bahasa Sumbawa yang jika diterjemahkan ke dalam bahasa Indonesia memiliki arti tajam. Pada tuturan tersebut, pemilihan kata merang yang digunakan NQD merupakan sebuah kata sifat yang merujuk pada suatu benda yang tajam. NQD bermaksud menyampaikan kepada lawan bicaranya bahwa benda yang dipegang oleh lawan tuturnya itu tajam. NQD mengeluarkan apa yang ada dipikirannya dengan pembendaharaan kata yang dimilikinya. Kata merang otomatis menjadi kata yang lazim di dengar oleh NQD di lingkungan tempat tinggalnya, sehingga spontanitas kata merang muncul dalam tuturannya tersebut. Adapun pemilihan kata merang yang dipilih NQD untuk menyampaikan maksud ujarannya dapat dikatakan sudah tepat, sebab kata merang sendiri bila digunakan baik dalam komunikasi antara teman sejawat maupun anggota keluarga memiliki arti dan makna yang tetap sama yakni menunjukkan sebuah kata sifat.

Selanjutnya pada data ujaran NQD yang kedua mengatakan ndak mau saya makan itu padang. Pada tuturan tersebut terjadi campur kode dengan adanya penyisipan leksikon bahasa Sumbawa yaitu pada kata padang yang jika diterjemahkan ke dalam bahasa Indonesia memiliki arti pedas. Kata padang sendiri merupakan sebuah keterangan kata sifat. Pada peristiwa tuturan tersebut NQD bermaksud menyampaikan penolakan kepada lawan bicaranya yang dalam hal ini adalah si ibu yang hendak memberikan makanan ringan namun ditolak oleh NQD dikarenakan makanan tersebut terlihat pedas. Pemilihan kata padang yang digunakan oleh NQD semata-mata karena perbendaharaan kata yang dimilikinya didapati berkat seringnya menyerap kosakata bahasa ibu yang acapkali didengar dalam berkomunikasi di lingkungan tempat tinggal si anak. Kata padang sendiri bila digunakan dalam tuturan kepada anggota keluarga ataupun teman sejawat memiliki arti yang sama jika digunakan dalam berkomunikasi di antara keduanya. Sehingga dengan kata lain dapat disimpulkan bahwa pilihan kata pada campur kode tuturan kedua NQD tersebut sudah tepat sebab memiliki arti dan maksud yang sama dengan apa yang ingin di sampaikan penutur.

$$
\text { Data ujaran ketiga NQD }
$$
slenjutnya yaitu saya lagi potong empaq. Pada tuturan tersebut terdapat campur kode dengan adanya penyisipan leksikon bahasa Sumbawa pada kata empaq yang jika diterjemahkan ke dalam bahasa Indonesia memiliki arti ikan. Kata empaq sendiri merupakan sebuah kata benda. Peristiwa tuturan tersebut terjadi pada saat NQD sedang bermain dengan teman sejawatnya yang dalam hal ini sebagai lawan tuturnya, sambil membawa tas jinjing mainan miliknya. Penggunaan kata empaq bila digunakan dalam berkomunikasi baik 
dengan anggota keluarga maupun teman sejawat, memiliki arti yang sama atau tidak ada perubahan arti jika digunakan dalam berkomunikasi antar keduanya. Sebab kata empaq seperti yang dikatakan sebelumnya hanya merujuk pada sebutan sebuah benda yaitu ikan. Dengan kata lain bahwa pilihan kata yang digunakan oleh NQD dalam tuturannya tersebut dapat dikatakan sudah tepat sebab memiliki arti dan maksud yang sama seperti apa yang ingin disampaikan dalam artian sebenarnya.

Data ujaran keempat NQD yaitu jangan tijak Alin. Pada tuturan tersebut terdapat campur kode dengan adanya penyisipan leksikon bahasa Sumbawa pada kata tijak yang jika diterjemahkan ke dalam bahasa Indonesia memiliki arti injak. Kata tijak sendiri merupakan bentuk kata kerja. Dalam peristiwa tuturan keempat tersebut, NQD bermaksud menyampaikan pesan kepada Alin untuk tidak menginjak sesuatu yang ada di depannya. Jika diterjemahkan ke dalam bahasa Indoneisa, data ujaran yang diucapkan NQD tersebut bisa bermakna ganda. Bagi orang yang berada di sebelah NQD dan lawan bicaranya bisa saja mengartikan bahwa NQD member peringatan untuk tidak menginjak Alin, padahal yang sebenarnya dalam hal ini NQD bermaksud memberi peringatan kepada Alin yang sebagai lawan tuturnya untuk tidak menginjak sesuatu yang di maksudkan NQD. Adapun penggunaan kata tijak jika digunakan dalam berkomunikasi antar teman sejawat dapat dikatakan sah-sah saja, namun berbeda halnya jika dituturkan kepada anggota keluarga khususnya orang yang lebih dewasa, kata tijak terdengar kurang tepat sebab terdengar sedikit kasar. Kata tijak sendiri merupakan hasil daripada penyerapan kosakata yang tentunya acapkali didengar oleh penutur di lingkungan tempat tinggalnya. Dengan kata lain, kata tijak dapat dikatakan sudah tepat sesuai arti dan maksud sebenarnya, selain itu dikatakan tepat jika digunakan dalam tuturan kepada teman sejawat sedangkan dirasa kurang tepat jika digunakan kepada anggota keluarga khususnya orangtua atau orang yang lebih dewasa dalam lingkungan keluarga si penutur.

Selanjutnya data ujaran kelima NQD yaitu nanti tumpak buek. Pada tuturan tersebut terdapat campur kode dengan adanya penyisipan leksikon bahasa Sumbawa pada kata tumpaq dan bueq. Jika diterjemahkan ke dalam bahasa Indonesia, kata tumpaq memiliki arti tumpah dan bueq memiliki arti habis. Jika diartikan secara kompleks ke dalam bahasa Indonesia , arti dari tuturan tersebut sebenarnya yaitu nanti tumpah habis. Adapun pilihan kata tumpaq buek yang digunakan NQD untuk mengungkapkan maksud pikirannya kepada lawan bicaranya yang dalam hal ini adalah si adik dapat dikatakan sudah tepat dari pemilihan kata namun masih kurang tepat dari susunan penggunaan kata itu sendiri. Kata yang dipilih NQD untuk menunjukan keterangan yang seharusnya adalah bueq tumpaq yang berarti habis tumpah. Adapun pilihan kata tersebut jika digunakan dalam berkomunikasi baik antar anggota keluarga maupun teman sejawat samasama bisa digunakan atau dapat dikatakan sudah tepat berdasarkan arti dan maksud dari tuturan itu sendiri sebenarnya.

b. Ketepatan Pilihan Kata dalam Campur Kode AHA

Data tuturan AHA yang pertama yaitu bembek tu, ada tai bembek. . Tuturan tersebut merupakan campur kode 
dengan adanya penyisipan leksikon bahasa Sasak pada kata bembeq yang jika diterjemahkan ke dalam bahasa Indonesia memiliki arti kambing. Bembeq dalam tuturan tersebut merupakan bentuk kata benda yang dalam peristiwa tuturan tersebut AHA bermaksud ingin memberitahukan lawan tuturnya yang dalam hal ini adalah teman sejawatnya bahwa ada kotoran kambing ke arah yang ditunjuknya seperti bulat-bulat kecil. Penyebutan kata kambing dengan sebutan bembek dilakukan AHA di luar pemahaman dan kesadarannya bahwa ia telah melakukan campur kode dalam ujarannya. AHA mengetahui arti kata yang digunakan dan mampu menghubungkan dengan objek yang diwakili. Adapun pilihan kata yang digunakan oleh AHA untuk menyatakan kata kambing ke dalam bahasa Sasak yakni kata bembeq dapat dikatakan sudah tepat. Tentunya pilihan kata yang tepat dan sesuai hanya dimungkinkan oleh penguasaan sejumlah besar kosa kata atau perbendaharaan kata yang dimiliki oleh AHA sebagai penutur. Selain itu, kata bembeq juga dikatakan tepat sebab bila digunakan dalam berkomunikasi baik itu dengan anggota keluarga maupun teman sejawat arti dan juga makna dari bembeq itu sendiri tidaklah berubah, sebab bembeq hanya merupakan denotsai dari nama hewan yakni kambing.

Selanjutnya data tuturan kedua AHA yaitu ndak sugul apinya. Tuturan tersebut merupakan campur kode dengan adanya penyisipan leksikon bahasa Sasak pada kata suqul. Dalam bahasa Indonesia tuturan tersebut memiliki arti tidak keluar apinya yang di mana kata ndak dalam bahasa Indonesia merupakan arti dari kata tidak pemakaiannya dalam ragam santai kemudian kata sugul yang jika diterjemahkan ke dalam bahasa
Indonesia memiliki arti keluar. Kata sugul sendiri merupakan bentuk kata kerja dalam bahasa Sasak. Pada peristiwa tuturan tersebut, pilihan kata yang digunakan oleh AHA yakni kata sugul dapat dikatakan sudah tepat berdasarkan arti dan maksud sebenarnya dan sesuai dengan situasi serta kondisi penggunaan kata-kata itu. Kata sugul juga tepat bila digunakan dalam berkomunikasi baik antara anggota keluarga maupun teman sejawat.

Selanjutnya data tuturan ketiga AHA yaitu ndek gemes saya. Tuturan tersebut merupakan campur kode dengan adanya penyisipan leksikon bahasa Sasak pada kata ndeq dan gemes yang jika diterjemahkan ke dalam bahasa Indonesia ndeq berarti tidak dan gemes berarti mau. Pada peristiwa tuturan tersebut AHA menyatakan sebuah penolakan secara tegas kepada teman sejawatnya ketika disuruh mengambil sesuatu dengan mengucapkan kata ndek gemes yang berarti tidak mau. Jika kata ndeq gemes digunakan dalam berkomunikasi dengan anggota keluarga khususnya orang yang lebih besar contohnnya kakak atau orang tua, maka kata ndek gemes sendiri kurang tepat dikatakan sebab terkesan seperti sebuah penolakan yang terdengar kasar, namun bila digunakan dalam berkomunikasi dengan teman sejawat boleh dikatakan sah-sah saja dan tepat untuk digunakan.

Selanjutnya data tuturan keempat dari AHA yaitu siapa mau taek ini yang jika diterjemahkan ke dalam bahasa Indonesia memiliki arti siapa mau naik ini. Tuturan tersebut merupakan sebuah campur kode dengan adanya penyisipan leksikon bahasa Sasak pada kata taek yang artinya naik. Taek sendiri merupakan bentuk dari kata kerja yang memiliki arti bergerak ke atas atau arah yang lebih tinggi. Pada 
peristiwa tuturan tersebut AHA bermaksud menanyakan teman-teman sejawatnya adakah yang mau ikut bersamanya menaiki kursi-kursi yang disusun menyerupai kereta api. Adapun pilihan kata taeq yang digunakan AHA dalam berkomunikasi dapat dikatakan sudah tepat, baik bila digunakan dalam berkomunikasi dengan anggota keluarga maupun teman sejawat kata taeq tetap sama-sama bisa digunakan sebab sudah tepat sesuai arti dan maksud dari tuturan penutur.

Selanjutnya data tuturan kelima AHA hujan beleq, siapa mau mandiq ujan.?. Tuturan tersebut merupakan suatu tuturan yang bersifat deklaratif yang menyatakan bahwa kondisi di luar sedang turun hujan, kemudian diikuti oleh kalimat pertanyaan. Tuturan tersebut merupakan campur kode dengan adanya penyisipan leksikon bahasa Sasak pada kata beleq dan mandiq yang bila diartikan ke dalam bahasa Indonesia kata beleq memiliki arti besar dan mandiq berarti mandi. Beleq sendiri merupakan bentuk kata sifat dalam bahasa Sasak dan mandiq merupakan bentuk dari pada kata kerja. Pada peristiwa tuturan tersebut AHA sebagai penutur bermaksud memberitahukan kepada teman-teman yang ada di sekitarnya bahwa di luar sedang turun hujan sekaligus menanyakan adakah yang ingin mandi hujan. Pada data tuturan tersebut pilihan kata yang digunakan dalam campur dengan adanya penyisipan leksikon bahasa Sasak ke dalam bahasa Indonesia bisa dikatakan sudah tepat, baik bila digunakan saat berkomunikasi dengan anggota keluarga maupun teman sejawat, sebab arti dari kata beleq dan mandiq itu sendiri sesuai dengan arti dan maksud sebenarnya di dalam bahasa Indonesia. c. Ketepatan Pilihan Kata dalam Campur Kode QIM

Adapun data tuturan pertama QIM yaitu waa, kenapa ade nan. Pada data tuturan tersebut terdapat penyisipan leksikon bahasa Sumbawa yakni pada kata ade dan nan yang jika diterjemahkan ke dalam bahasa Indonesia ade memiliki arti yang dan nan berarti itu. Kata ade nan yang dimaksudkan QIM di sini merupakan sebuah kata penunjuk dan di awali dengan kata fatis waa dalam bahasa Sumbawa dengan intonasi yang sedikit panjang. Pada peristiwa tuturan ini, QIM melakukan campur kode diluar kesadarannya dengan maksud ingin mengemukakan sesuatu kepada orang lain yang dalam hal ini anggota keluarganya, selain itu juga dikarenakan ingin memberikan reaksi terhadap sesuatu yang yang dilihatnya dengan menggunakan bahasa yang dipahami dan biasa di dengar di lingkungan tempat tinggalnya. Pada data tuturan tersebut, pilihan kata yang digunakan QIM dapat dikatakan sudah tepat baik bila digunakan pula dalam berkomunikasi dengan teman sejawatnya. Ketepatan pilihan kata itu sendiri dikarenakan memiliki arti dan maksud yang sama dengan apa yang ingin disampaikan penutur sesuai dengan situasi dan kondisi yang dimaksudkan.

Data tuturan kedua QIM yaitu kita tunggu dia sampai jira besikir dunu. Pada data tuturan tersebut terdapat campur kode penyisipan leksikon bahasa Sumbawa yakni pada kata jira, besikir dan dunu. Jika diterjemahkan ke dalam bahasa Indonesia, kata jira memiliki arti selesai, besikir berarti berzikir atau biasa dikenal dengan istilah tahlilan dalam kegiatan hajat di kampung baik tasyakuran maupun kematian, serta dunu memiliki arti dulu atau dahulu. Peristiwa tuturan tersebut merupakan sebuah pertanyaan yang tuturkan QIM kepada anggota keluarga yaitu si ibu, yang dimana ibu saat itu 
berperan sebagai lawan tuturnya. QIM bermaksud akan pergi ke suatu tempat bersama ayah namun harus menunggu si ayah selesai acara hajatan di dekat rumahnya. Pada data tuturan tersebut, pemilihan kata yang digunakan dapat dikatakan sudah tepat sebab arti maupun maksud dari tuturan tersebut sama dengan arti sebenarnya yang dimaksud oleh penutur.

Selanjutnya data tuturan ketiga QIM yaitu waa jina penokna op sudah. Pada data tuturan QIM tersebut terdapat campur kode dengan dominasi leksikon bahasa Sumbawa yang digunakan yakni kata waa, jina, penokna, dan op yang kemudian diikuti oleh bahasa Indonesia di belakangnya. Kata waa di sini merupakan suatu bentuk ungkapan keluhan dari si penutur yang masuk pada kategori kata fatis, jina sendiri memiliki arti terlalu, penokna berarti banyak dengan kata dasar penok dan di berikan akhiran -na sehingga jika dalam bahasa Indonesia memiliki arti banyaknya, sedangkan op di sini memiliki arti cukup. Secara keseluruhan, arti daripada tuturan tersebut yaitu waa terlalu banyak sekali cukup sudah. Data tuturan tersebut merupakan sebuah kalimat penolakan yang di tuturkan QIM kepada lawan bicaranya yang dalam hal ini anggota keluarganya. Adapun pilihan kata-kata yang digunakan QIM tersebut dalam tuturannya dapat dikatakan sudah tepat dikarenakan sesuai dengan arti dan maksud yang sebenarnya dari apa yang hendak disampaikan oleh penutur baik bila digunakan saat berkomunikasi dengan anggota keluarga maupun teman sejawat.

Selanjutnya data tuturan keempat QIM yaitu oo kakak itu $h p$ kakak ee di anok meja. Pada data tuturan tersebut terdapat penyisipan leksikon bahasa Sumbawa yakni pada kata anok yang jika diterjemahkan ke dalam bahasa Indonesia memiliki arti bawah. Arti dari tuturan tersebut secara keselurahn dalam bahasa Indonesia yaitu kakak itu hp kakak di bawah meja. Pada peristiwa tuturan tersebut, QIM bermaksud memberitahukan lawan tuturnya yaitu si kakak yang sedang kebingungan mencari sesuatu bahwa yang dicari-cari si kakak ada di bawah meja. Adapun pemilihan kata anok pada campur kode tuturan tersebut dapat dikatkan sudah tepat sebab kata anok merujuk pada kata tempat baik letak, sisi, bagian, dan arah yang leih rendah sesuai dengan arti dan maksud yang ingin disampaikan oleh penutur. Kata anok juga tepat bila digunakan saat berkomunikasi dengan teman sejawat sesuai situasi dan kondisi yang dimaksud.

Data selanjutnya QIM yang kelima yaitu satu sama dua na teres tiga na. Pada tuturan tersebut, terdapat penyisipan leksikon bahasa Sumbawa yakni pada kata teres yang memiliki arti lalu atau kemudian. Kata teres merupakan bentuk kata penghubung pada sebuah kata maupun kalimat yang biasa digunakan dalam bahasa Sumbawa, sedangkan kata na pada tuturan tersebut merupakan kata fatisnya. Tuturan tersebut terjadi pada saat QIM sedang berbicara dengan anggota keluarga yang dalam hal ini adalah si ibu yang sedang mengajar penjumlahan. Adapun pilihan kata pada campur kode yang digunakan QIM dalam tuturan tersebut dapat dikatakan sudah tepat sebab arti dari teres itu sendiri sama dengan arti dan maksud sebenarnya yang ingin disampaikan oleh si penutur, serta tepat dan biasa pula digunakan dalam berkomunikasi dengan teman sejawat. 


\section{KESIMPULAN}

Berdasarkan hasil penelitian dan pembahasan pada bab IV sebelumnya, peneliti menyimpulkan bahwa pada tuturan anak usia dini NQD, AHA dan QIM dalam berkomunikasi dengan anggota keluarga dan teman sejawat acapkali menyisipkan leksikon bahasa daerah atau bahasa ibu si anak ke dalam bahasa Indonesia. Adapun pilihan kata yang digunakan dalam campur kode ketiga anak tersebut dapat dikatakan dominan sudah tepat sebab secara arti maupun maksud dari tuturan yang digunakan dalam bahasa daerahnya sama dengan arti yang sebenarnya dan tidak merubah makna dan maksud dari tuturan itu sendiri di dalam bahasa Indonesia

\section{SARAN}

Penelitian ini diharapkan dapat menambah pengetahuan mengenai studi analisis terhadap penggunaan bahasa anak usia dini. Selanjutnya yang kedua, penelitian ini diharapkan dapat dijadikan sumber acuan serta pemanfaatan dalam bidang penelitian yang relevan dengan permasalahan campur kode serta gejala kebahasaan yang terjaadi pada anak dalam penelitian sejenis lainnya. Kemudian yang terakhir harapan bagi orangtua, kiranya dapat menjadikan penelitian ini sebagai gambaran serta edukasi akan pentingnya membimbing anak dalam hal penggunaan bahasanya ketika berkomunikasi dengan lawan bicaranya agar si anak dapat berbahasa dengan baik dan benar sesuai situasi dan kondisi.

\section{DAFTAR PUSTAKA}

1993. Prinsip-prinsipPragmatik.

Bogdan, Robert dan Steven J. Taylor. 1992. Pengantar Metode Penelitian Kualitatif. Surabaya: Usaha Nasional.

Chaer, Abdul dan Leonie Agustina. 2004. Sosiolinguistik: Perkenalan Awal. Jakarta: RinekaCipta.

Chaer, Abdul. 1995. Pengantar Semantik Bahasa Indonesia. Jakarta: Rineka Cipta.

Chaer, Abdul. 2002. Psikolinguistik: Kajian Teoretik. Jakarta: Rineka Cipta.

Chaer, Abdul. 2003. Linguistik Umum. Jakarta: RinekaCipta.
Clark, V. Eve. 2009. First Language Acquisiton. New York: Cambridge University Press.

Dardjowidjojo, Soenjono. 2003. Psikolinguistik: Pengantar

Pemahaman Bahasa Manusia. Jakarta: Yayasan Obor Indonesia.

Fuad Abdul Hamid. 1987. Proses Belajar Mengajar Bahasa. Jakarta: Depdikbud, Dikti, P2LPTK.

Ihsan, Dimroh. 2011. Pragmatik, Anasilisis Wacana, dan Guru Bahasa. Palembang: Universitas Sriwiwjaya. Jakarta: PT Gramedia Pustaka Utama. Jakarta: Universitas Indonesia.

Keraf, Gorys. 1984. Diksi dan Gaya Bahasa.

Kridalaksana, Harimurti. 2008. Kaтиs Linguistik. Jakarta: Gramedia Pustaka Utama.

Leech, Geoffrey. (Terjemahan M.D.D. Oka).

Levinson, Stephen C. 1987. Pragmatics. Cambridge: Cambridge University Press. Mar'at, Samsunuwiyati. 2005. Psikolinguistik Suatu Pengantar. Bandung: PT Refika Utama.

Nababan,P.W.J. 1987. Sosiolinguistik Suatu Pengantar, Jakarta: Gramedia.

Pateda, Mansoer. 2010. SemantikLeksikal. Jakarta: Rineka Cipta.

Purwo, Bambang Kaswanti. 1990. Pragmatik dan Pengajaran Bahasa: Menyibak Kurikulum 1984. Yogyakarta: Kanisius.

Soemarsono dan Pratana Paina. 2004. Sosiolinguistik. Yogyakarta: Sabda.

Suwito. 1983. Pengantar Awal Sosiolinguistik Teori dan Problema. Surakarta: Henari Offset Solo.

Verhaar, J.W.M. 1996. Asas-Asas Linguistik Umum. Yogyakarta: Gadjah Mada University Press.

Yule, George. 1996. Pragmatik (Terjemahan Indah Fajar Wahyuni). 2006. Yogyakarta: PustakaPelajar 